\title{
Kazakhstan: The Choice of Civilizational Priorities
}

\section{A. Sh. Alimzhanova}

\section{G.T. Aldambergenova}

\section{T.S. Mantayeva}

\section{T.H. Gabitov}

\begin{abstract}
Associate professor of Kazakh national academy of arts named after T. Zhurgenov. Candidate of philosophy sciences Almaty, Kazakhstan, Professor of Kazakh national academy of arts named after T. Zhurgenov, Doctor of pedagogical sciences PhD student, Al-Farabi Kazakh National University; Professor Al-Farabi Kazakh National University, Doctor of philosophy sciences
\end{abstract}

\section{Doi:10.5901/mjss.2015.v6n5s1p582}

\begin{abstract}
This article discusses some aspects of the approach to pre-Islamic cultural heritage in the history of the spiritual quest of the Turkic peoples. Comparative data analysis of the relationships of various ethnic cultures of their spiritual heritage has been given and it has emphasized that respect for cultural heritage as a sign of civilization. Subjected to critical analysis of a variety of negative attitude towards the cultural heritage of the Kazakh people (Eurocentrism, ethnonihilism, particularism, fundamentalism, passeizm, etc.). Spiritual values had been formed during centuries - old world discovery by the Kazakh people, originally joined knowledge and morals, mind and will, beauty and humanity and they were concentrated in postulate: «Be just a man!». In their works Kazakh writers, poets stated that understanding of himself, his place in this world and meaning of his existence are possible through the relationship to other people. This is controled by his conscience which is the inner support for a man.
\end{abstract}

Keywords: Cultural heritage, tradition and innovation, globalization, identity, spirituality, dialogue of cultures.

\section{Introduction}

The lost of historical memory is the lot of mankurt (spiritual blind person). If this disease takes one person, it becomes misfortune. It becomes a tragedy when whole nation suffers from this disease. And it is precisely the loss of historical memory dazzled us in recent times, when whole generations were unavailable to achieve humanistic values of world civilization, and the heritage of its own nation (during the Soviet Union period). There were known facts of attempting to ban and concealment of many works and thoughts of famous historical figures, philosophers, historians, lawyers, and others. With the acquisition of Kazakhstan's independence, at last, it's time the revival of genuine spirituality, historical memory, entering the mainstream values of whole human civilization. After a long and painful slumber, it becomes possible, with a huge thirst for knowledge, to turn to the ever living source of human spirituality. It became necessary to quench that thirst, but it must be done at the level of the requirements of the methodology and values of the modern information civilization, avoiding distorting mirrors and creation of new myths. That is what is aimed in initiates of the president of Kazakhstan Nursultan Nazarbayev's governmental program "Cultural Heritage". The development of the spiritual heritage of past generations, recovery of historical memory will open the way for the prosperity of Kazakhstan.

Values according to selected targets in the field of spiritual development strategy "Kazakhstan - 2030", where the health, education and welfare of citizens are identified as the top priorities (Baltabayev M.H., 2003). The starting point for the practical implementation of the reform of society should be the unity of the process of production of material goods and the development of an individual. Items attributed to cultural values are "the moral and aesthetic ideals, norms and patterns of behavior, languages, dialects and sub-dialects, national traditions and customs, historical place names, folklore, arts and crafts, works of art and culture, methods and results of scientific research of cultural activities which have historical and cultural significance, buildings, structures, objects and technology, unique in the historical and cultural area" (Kodar A. and others, 2000). This implies that the core of cultural values of the Republic of Kazakhstan is the products and artifacts, state and potential of the creative art of the peoples of this country. A.N. Nysanbayev states: "Becoming a sovereign state, Kazakhstan, like other countries must realize that Kazakhstan has no permanent friends 
and permanent enemies, but only eternal national interests. If they are ignored, it can quickly undermine the young and feeble country" (Nysanbayev A.N., 1999).

\section{2. "West" and "East" Concepts in Globalization Context}

Meaning of the life is always topical question for humankind. Especially this issue became important on the threshold of the 21st century. A man stopped to think over analyzing and evaluating the outgoing century. What good and evil sides did that century have? What will we have in our luggage stepping from one century to the next? One thing is certain: we have young to be proud before descendants, but we have much to be ashamed. "The twentieth century has been the worst in the history of human civilization. In the series of global anxieties century were fascism, totalitarism, with its massive repression, forcing large numbers of people leave their homes, hunger, walking on the planet, growing up to universal scale environmental problems " (Nysanbayev A.N., 2004).

In the twentieth century colonial empires have fallen, but the relationship has not disappeared, just changed the form of its execution. Economic chain is not less strong than the military-political. On the world stage there raised a new type of empire - a superpower. Humanity is proud of the achievements of scientific and technological progress and economic growth. And it is absolute fair. The human mind has penetrated into the microcosmos, mastered nuclear energy. He has reached the heights in rocketry and astronautics. There got great achievements in television and radio communications, microelectronics and molecular biology.

But what is in the other side? More and more sophisticated and destructive weapons, the environmental crisis and the creation of a consumer culture, catastrophically losing spirituality and filling the vacuum industry pleasures. Increasing economic inequality, the extreme poverty of some and over enrichment of others. Ch. Aitmatov and M. Shakhanov in their dialogue "Crying over a precipice Hunter (confession at the end of the century)" pay attention to these problems.

From the point of view of M. Shakhanov, our civilization approached to the brink of a precipice because the spirit priority is forgotten. He writes that the western mind which has destroyed traditional values and under the badge of scientific experiment (at the beginning of a century) anatomizing and systematizing «the three-dimensional world», addressed then to a life's wrong side, to the dark, "return" side» of a human nature and the world. «All forbidden, unusual, unknown draws of its sick attention, and habitual and traditional, "positive" lost any interest and value. This fundamental installation of the European consciousness defined the general atmosphere and cultural orientation of the West at the end of the 20th century» (Aitmatov Ch., Shahanov M., 1996).

Ch. Aitmatov totally agrees with him. «What a pity that for a long time we didn't pay attention on this fact. Alive person is weaved from different actions: creative and destructive, deliberate and spontaneous. Labyrinths of internal life of the person are difficult and dangerous. But anyway, to prevent the birth of the blood-sucker from the blood-sucker, villains from the villain, to besiege plague of a mankurtizm starting up in revelry and a zombizm - the greatest duty of all mankind» (Aitmatov Ch., Shahanov M., 1996).

Who can be responsible for this immorality? How is it possible to be sure for the country future when the future generation is absorbing doubtful values made from cheap literature, the low-standard commercial films penetrated by spirit of violence, murder, a robbery!? In our society concept of democratic freedom is understood improperly. The television is fulfilled with films about violence, mockeries and tortures, book counters burst with low-standard melodramas, fighters and thrillers, which has nothing common with high art, propagandizing and introducing the "way of life" which alien to strategic ideals and traditional ethics of national experience in consciousness of our people. «Where in a basis of education lies murder, we will receive either the kamikaze or James Bond» (Aitmatov Ch., Shahanov M., 1996). Owing to this fact the European culture winds to this day on hell circles, in forces to overcome an attraction of destructive temptations and ideas... Oriental experience of overcoming of this problem isn't always applicable to the western consciousness alien to metaphysics and based on rational mentality, though the West is on the threshold of opening of meta-historical reality and methods of its comprehension (Aitmatov Ch., Shahanov M., 1996).

According to scientists, 20th century became the tragedy for a human civilization because it subjected its foundations to the various social experiments which destroyed and have carried away them, irrespective of a nationality, the religion, carried them away to utopian idea of social equality. As result world outlook values, spiritual reference points, the main living positions of people have been destroyed (Aitmatov Ch., Shahanov M., 1996).

Results of this process are so plentiful that it is impossible not to notice them. They entered into our life and became its integral part. It is crime, terrorism, corruption, vandalism, alcoholism, drug addiction, fanaticism and many other things. When opposition of two ideologies left after emptiness and captured by a panic and fear of people ended, there were even more favorable circumstances for extremists of all colors, beginning from politicians, finishing platform and cinema "stars", not to mention the sphere of criminal "pleasures". 
As product of urbanization raised new community, which has received new definition "the masses", where borders patrimonial lines as the personality, and ethnos are slowly but surely deformed. The city a framework of the limited space presses people, their will and destinies, concentrating in itself huge potential of social energy. In the same borders concentrates huge man-triggered energy in the form of giants of the industry, objects of the increased danger to the person and environment.

The number of man-triggered and natural disasters, emergency situations grows. Probability of one person to influence to whole universe is increasing. All this occurs in the environment of the expanding mass which cannot be structured, has no traditions, and inadequately reacts to occurring events, averages and it depersonalizes the person. The mass is easily excitable, cruel and irresponsible - it is the fine environment for suggestion and «social zombing». It is possible to title 20th century an eyelid of urbanization and the masses which has acted as essentially new generator of social energy, the carrier of mass ideologies, mass cultures, radical quasi religions.

Civilization of any state is defined, first of all, by its relation to a cultural heritage. Before a state policy of Kazakhstan in the field of culture there is a double task: on the one hand it is necessary to develop a complex of the actions directed on development and maintenance of original ethnic cultures; with another - creation of conditions for optimum development and painless integration into uniform of universal culture. As it is stated in the concept of social cultural development of the Republic of Kazakhstan, the cultural heritage allows the people to remember traditions of the past, to derive spiritual strength, skillfully introduce it in lines of other cultures for development of process of consciousness. The identity of national cultures from the unity of the cultural values of the people of Kazakhstan. Therefore the Republic of Kazakhstan will keep and protect a cultural heritage of all people, will provide equality of cultures and the right of each people to approve, preserve and develop the cultural originality.

Careful relation to own cultural heritage and the perception of valuable elements of other cultures is the unique way of development of human civilization. All its main achievements are obtained in this way. For example, we all admire the achievements of medieval Muslim culture in the period of the beginning of $9^{\text {th }}$ century and $13^{\text {th }}$ centuries, which is considered as Islamic Golden age. In that period was recognized as the second teacher al-Farabi who wrote his immortal treatise, Avicenna completed his 12 volume work on medicine, Khoja Ahmat Yassawi raises human spirituality to an unprecedented level, urban culture of Central Asia provides the most advanced patterns of material and spiritual culture, etc. for that time. Researchers of this phenomenon point to many reasons and factors of heyday of the culture (synthesis of Arabian, Iranian and Turkic cultures, the role of the Great Silk Road, the dynamics of the nomadic civilizations, the role of Islamic civilization and spiritual potential of Tengrianism, Zoroastrianism, Manichaeism and other indigenous religions and etc.). But I want to draw attention to one more situation and it is connected with the translation of the cultural heritage of humanity. It is well-known fact that Caliph al-Ma'mun in Baghdad, the capital of the Arab Caliphate, contributed to the opening of the House of Scientists in the city and asked to translate into Arabic English major works of ancient Greek philosophers and thinkers. All this contributed to the dialogue of cultures and through it to its heyday. Beginnings of the President on the state program "Cultural heritage" can be compared with the acts of the Caliph Mamun.

Problems of revival of cultural heritage are closely related with mental essence of people, it affects meaning of life aspects. Cultural heritage - is a testament of one generation to the next as connecting thread. As a French moralist de Chamfort writes, what can most of people see in it, when society is not sealed with mind, not quickened sense, when there is no origin of benevolence and sharing worthy? He can see only fair, gambling houses, hostelry, and bandit den. But the memory remains and imperishable creations of ancestors live. Ancient nomads were right to understand their actions and perceive what is happening in the world as a common desire and common human creativity. Past is not what passed and will not return, the future is not what is waiting for us then, and all of them are woven into the present.

Analyzing the role and place of cultural heritage in long-term development of the country, there's always a problem, which cannot be ignored as a ratio of the tradition and innovation in the social and cultural dynamics of the country. There can be distinguished three forms of interaction:

1) Resistance and boycott of the new, return to the old order and values;

2) Breaking tradition by borrowing new values and orders;

3) Transformation of the new and making it acceptable to tradition forms.

If values of growth and development exist (or it easily implanted) in traditional culture, the elements of modernization, innovation, it is accepted to say about the society in which these elements have space for development, as the best traditional society. The connection of the values of modernization with the national cultural identity creates the possibility of realization of the optimistic scenario of the way of entering the modern civilization. This core feature of constructive and practical effective cultural policy more fully expressed in Japan, works effectively to economic prosperity "young dragon" of Southeast Asia, which has proved its resilience in the modernization of China. Implementing the state 
program "Cultural Heritage", the Republic of Kazakhstan should take into account this experience. However, the revival of the practice of cultural heritage through the absolute cultural and ethnic identity, the construction of a new "Chinese wall" between the East and the West, the North and the South in an attempt to reform, for example post-colonial and posttotalitarian countries, and rejection of modern globalization slogans, which show us religious and political nationalism in some countries of the Muslim East, African Negritude theory, ideas of Chuchhe and etc. all of these demonstrate their ineffectiveness or even have a devastating impact on the culture, economy and society.

Program of 'Cultural Heritage' is being realized in the conditions of development of globalization and westernization processes. In the past it seemed that globalization will lead to unification and westernization will be peculiar to whole nations. However process of mastering of the west culture, gave contradicting results. West civilization formed without participation of oriental countries passed limits of ethnical culture and begins claiming universalism. Ideals of oriental cultures (sense of harmony, harmony between a man and a nature, reconciliation of extremes, religiousness etc.) were not attached to the western culture and predetermined formation of non-Western type of an individual.

Turning to the monuments of history and culture is an indicator of our spiritual maturity and inner freedom. What course of action should I choose to remain a free man, in order to survive in this an imperfect, sometimes absurd world? Initially, a person needs support to self-affirm for his human essence in this absurd world. This support can be served by different things. But you never know how people can claim their separateness, individualism. Now liberal education in broad sense of its meaning should be considered as support for self-affirmation. Glory of an individual is confirmed by his education, his freedom and dignity are inconceivable without the knowledge which is received as a result of the assimilation of cultural heritage, both his national and the whole mankind.

An educated man, feeling the past, nature, space, as part of his life, as his ancestral house and who feels his need in their care, is a very special person. It is impossible for him to lose or forget the past. He will not be looking at cultural values and history heartlessly. But he will try to understand, to feel, to hear the voices, issues of the past, the experience of others. Therefore, cultural heritage is cultural dialogue, time dialogue.

"To feel something alien as native" - translation greatly helps this communication strategy of culture, as it provides intercultural communication in the level of texts. To some extent every cultural activity can be considered as communicative, because it contains and expresses certain information. The communicative aspect grows into the cultural dialogue in translation.

Therefore, we consider translation as a channel of initiation to global cultural heritage, as a way to enrich your own cultural resources.

Typically, a large number of problems emerge during translation of information from one language to another. The greatest difficulty in contact with another culture increase due to the inability to acquire symbolic space because of ignorance of its cultural code. Obviously, that an accurate translation is impossible because of the different images of the world created by different languages. The development of another language, and its use - whether it is a live communication or translation - mediates the new position of "the old view of the world".

On the crest of a wave of information civilization of culture permeates either in the field of direct creation, and either in the start of production, life and human existence itself. This concentration makes a person be responsible for his fate. Personality is open to freedom. That motivates him to cross all borders, bypassing the line between good and evil, within temptation of self-assertion, in focusing only himself (egoism I). Conflict of aspirations awakens conscience, finds man at crossroads (there is a struggle between good and evil) and requiring him to act on the decision, which, however, does not guarantee his (human) goodness till the rest of his life.

Dialectic of global social-spiritual processes of $20^{\text {th }}$ and the beginning of the $21^{\text {st }}$ centuries in dramatic peripeteia had enriched philosophy of civilization with new behavior stereotypes where general universal does not exclude patriotic, cultural heritage consolidated as component of the universe. Cultural heritage is confessed as initial environment of transformation of general human moral rules into national cosmos and contemporary interest to its canons is certainly, sign of humanization of a society. In the other hand, idealization of the ancient experience which reached to us in deeprooted forms of way of life and mythologized comprehension of phenomena of the reality would mean in the epoch of qualitative change of general environment of humankind and dynamism of all sides of his life as such halt in development without which essence of an individual would lose any meaning. So, in the art it is justified doubts of personage as condition caused in one hand by trouble, from the other hand with difficulty of rationalization of contemporary phenomena of human activities, and with imperfectness of established moral categories.

In spite the fact of enormous technical achievements of contemporary civilization, in the sphere of cultural heritage and moral culture it is facing with serious crisis phenomena. Beside world economic crisis, humanity is experiencing either poverty of his moral, spiritual basis. This is reflected in relations of a man and the universe, man and man.

We cannot ignore either influence of features of the $20^{\text {th }}$ century to the psychics of a man: wars, concentrations 
camps, repressions and political issues, unceasing waves of crisis situations almost in all spheres of human activities which came as heritage to the $21^{\text {st }}$ century. It is peculiar tragedy of an individual which is numerous times faced before his moral choice.

Mutual hatred, national disagreement, superstitions and prejudices, fanaticism have been tormenting humanity transferring from generation to generation as frightful heritage, as gloomy perdition which is hanging over people. Beside these social vices human hearts were suffering torments with eternal problems, with eternal confrontations between life and death, physical illnesses and health, beauty and jealousy etc. It becomes vivid that society of consumption does not have the future, there is too much of spiritual costs. It has already become clear its resource and economic extents.

Dream about a man and humanity, far from all cultural heritage, is loss of the whole world of values and wealth. Culture has never been and will never be human abstractedly. It is always concrete i.e. national, individual, peculiar to people. Only in this feature it can reach general humanistic level.

N. Berdyaev writes: 'A man enters to humanity through national individuality, as national person, but not as abstract man as Russian, French, German or English man... National man is more than a simple man. He has general genetic and individual national features. One can wish unity and friendship of Russians, French people, English men and Germans and all the other nations of the world. But we cannot wish that features of national identities, national spiritual types and cultures have been disappeared in the earth' (Berdyaev N.A., 1990).

One of the main themes of contemporary art is search of spiritual moral orientations which would let a humanity to feelconfidence in new historical circumstances. Moral and aesthetic values of cultural heritage are formed in the process of art creation. An artist creates artistic composition which creates artistic reality expressing artistic thinking with aesthetic impact. For creation of artistic composition, he uses figures and artistic reality is created through artistic methods and means, which compose arsenal of art. Whole creativity process represents multi-level and multi stage action which can be imagined as construction of house of artistic reality where artistic reality lives. Building materials for this house are flowers, light, sounds, words, actions etc. All these represent the part of aesthetics which is titled as sphere of artistic activity of people. Widening this image to artist creator, we can see that he must be simultaneously producer of fabrics, builder and architecture. Who will settle in the house depends on the author's professionalism? According to M. Bakhtin: 'author is a sole forming energy which is not given in psychologically concept consciousness but in significant cultural product and its active reaction is given through its conditioned structure of active vision of a character as whole unity in the structure of its image, rhythm, in intonation structure and choice of notional moments' (Bakhtin M.M., 1986).

Art (rather its creation) is imperishable. It is connected with people as with 'consumers' of creativity, with condition of their spirituality, deformed irrelevance of art. It is related with added to historical field of art with new lands which can be sewn not with grass, but with noxious weeds. What is more if not to discard that grayness, banality from art; it will feed humanity with all its assortment.

Art as science could not resist to powerful stream of the $21^{\text {st }}$ century which involved it into industry of satisfaction and transferred it into a kind of commercial spiritual 'bacon' which captures taste of consumer: sharp feelings, illusions, hallucinations etc. Academician D.S.Likhachev stated: 'I do not believe into progress in decrease of culture' (Lihachev D.S., 1989).

Human spirit is a casket with numerous unsolved riddles. Who can guarantee that ascended sprout of kindness will not be swept and trampled by vindictiveness and exasperation caused by life difficulties and deprivation? Sometimes life circumstances and environment can lead a man to obduracy. "Cruelty generates cruelty» (Aitmatov Ch., Shahanov M., 1996).

It is possible to title $21^{\text {st }}$ century as century of informational technologies and the masses which has acted as essentially new generator of social energy, the carrier of mass ideologies, mass cultures, radical quasireligions. Development of informational technologies lead to replacement of technologies which aimed to get necessities of material values and services for people, with technologies of 'abstertion' of brains aiming to get required type of consciousness and culture. Informational boom, communicative nets and unbelievable impact on all human organs of sense. This is the only abundance which man knows. This is an abundance to aversion and dullness.

All problems of an individual and collective character lie in human nature. At the turn of centuries the life arises really significant question: will we be able to wake up earlier than the concentration of exposable problem will achieve its critical point?

Crisis of spirituality is related with unceasing cataclysms, because of which a human is perishing, hardening, losing his social relations and stops believing to anyone. His soul is emptied. It appeared absolutely new situation. It is going feverish search of guides, mechanisms, balances and by his natural essence a human is arriving to the simple social relations. On this basis there are easily developing religious and political charlatans and totalitarian monsters. People are searching for love but facing holders of kindness with claw or they are directly worshipping the evil. 
As M. Orynbekov states: 'Moral decline is highly influence to youths, since they are devoid from ideals of purity and loyalty, wisdom and honor from the early childhood and as result they gravitate to betrayal, squabbles and scandals» (Orynbekov M.S., 1995). Today it is the most appropriate time to think about with what thinking and feelings we are entering to the future. Will we be able to wake up a human in a human?

Crisis of humanism in the world brings up problem of a human to stay a man in a spiritual meaning rather that rational person, a man with conscience. Ch. Aitmatov writes: 'the worst of the threatening dangers for us is neither atomic, neither heat or other similar threatens of physical destructions of humanity (probably of all the universe) in the Earth, but rather destruction of humanity in human. This is a catastrophe which means that a human could not become a human» (Aitmatov Ch., Ikeda J., 1994).

Revival of national self-consciousness should be begun from up-bringing of youth who are the future of a country. Youths must have good higher education, developing high intellectual level and civic maturity. It is necessary to revive unity of intensions and aspirations which will be ruled by honor and will make regulations. It is necessary to get united in the sake of preservation of unique spiritual culture, mother-tongue, history and sovereignty.

In contemporary society there are enlarging such negative conditions and temper as loss of belief and decrease of role of religion, disappointment in ideologies and political systems, loss of belief to heads and higher leaders, widening scepsis to science, extended approach to social unfairness. Because of all these factors concepts of love, kindness, truth and consciousness are disappearing, stagnation of art and entrance to it of different types of surrogates significantly strengthens tendency of loss of 'eternal' values. Lack of moral ideals and impersonality of moral norms are badly influencing on spiritual condition of people.

National systems of morality peculiarly form universal moral concepts. The simplest of moral ideas include respect for elders, patriotism, hard work and solidarity. They accumulate in the concept of the conscience of the people.Conscience of the nation, constantly guarded and multiplied by its best representatives, is inseparable from the state, the vast expanses of land, from her soul - culture and language. Live and work in good conscience is inherent, perhaps, to all nations and people, but to the Western mentality is typical to live by the rules, the laws, whereas we traditionally from generation to generation commandment to live honestly, in order not be ashamed before the memory of ancestors and court of the descendants.

The general concept of morality cannot be reduced either to the will of the Supreme Being, or to an inherited capacity for self-sacrifice, or to service to the economic and political interests of certain social groups.

It is important to emphasize that today it is necessary to abandon the idea of the existence of one, the only true morality. Each of the areas of morality has in its content a rational principle, reflects some real aspect of this phenomenon. The closest to the truth is the understanding of morality as a separate, stand-alone part of human existence expressing its special quality - quality of humanity.

Inner world of a man is the main thing that determines the moral value and moral character of an individual. Understand oneself and one's place and meaning of existence is possible only through relation to other people, to society. Man lives in the complex world of the intersection of the natural and social, individual and social, private and collective.Moral condition of the people depends on relations in society.

\section{Conclusion}

To become a man, Homo sapiens, he needs a soul - a special light of the Supreme Spirit. Spirituality itself is recognizable by certain criteria. One of its main features is unselfishness, which protects from the alienation from humanity, patriotism, personal thoughts and ideals of service to the fatherland. It is an indicator of spirituality of the society and civilization of public relations, protecting the souls of men from moral corruption, callousness. Culture is based on the spiritual consequence of spirituality, civilization. A spiritual aspiration creates prerequisites for the ideal, the possibility of perception and concentration of national and universal values. Values are shown where there are spiritual prerequisites, the culture, education, interest in the development and enrichment of national and universal values, and through them - to the affirmation of the nation in the civilized space.

By recognizing the world, philosophy directs people to the truth. These changes of the psychological state are directly related to the development of society's spirituality, art is the core and the main means of an esthetic education. The best result of this union - the formation of a coherent and harmonious, self-sufficient and socially valuable, creatively active personality with high culture, which allows a person to live humanely and act with conviction, focused, selective, productive, practical and with universal significance.

Any person sees himself as a representative of the human race and as a member of a particular ethnic group, nation. As a representative of the human race, the individual acts as a carrier of universal values - goodness, beauty, 
truth, freedom, justice, etc. As a representative of a particular ethnic group or nation he shares the values of the individual ethnic group or nation: loves his country, feels proud for belonging to his ethnic group, and esteems his language, culture, and historical past of his nation.

But, as a rule, the individual does not share the kind of universal and national values. However, human values, usually appears before him in the national-ethnic appearance. Fathom the world of culture, man knows the ideas and ideals, languages and standards of behavior, which leads to understanding and perception of the spiritual and moral principles, ideas of goodness, beauty, good, truth, and justice. These values guide the motivations and the motives of man, interests and goals of the identity, form his spirituality.

\section{References}

Baltabayev M.H. (2003). Modern Art Culture of Kazakhstan. - Almaty, - P.71

A. Kodar and Others. (2000). Culture and the Media: Issues of Interaction // Law of the Republic of Kazakhstan from December 24,1996 on "Culture" - Almaty: ID «Credo», - 360 p.

Nysanbayev A.N. (1999). Kazakhstan. Democracy. Spiritual Renewal. - Almaty: kaz. Encyclopedia, - 416.

Nysanbayev A.N. (2004). Globalization and Problems of Intercultural Dialogue. In two volumes. - Astana: KIPP MES. V.2., - 308 p.

Aitmatov Ch., Shahanov M. (1996). Crying Hunter Over the Abyss (Confessions at the end of the century). - Almaty: Rauan, - 384.

Berdyaev N.A. (1990). Destiny of Russia. - Moscow: Moscow State University Press, - 240. (95-96).

Bakhtin M.M. (1986). The aesthetics of verbal creativity. - Moscow: Art, - 445 p. (183).

Lihachev D.S. (1989). About Good and Beautiful. - Moscow: Child. Lit., - 237 p. (205)

Aitmatov Ch., Shahanov M. (1996). Crying Hunter Over the Abyss (Confessions at the end of the century). - Almaty: Rauan, - 384. (120121).

Orynbekov M.S. (1995). Abai's Opinion of Philosophy. - Almaty: Bilim, - 136 p. (114).

Aitmatov Ch., Ikeda J. (1994). Oda to Greatness of Spirit. - Moscow: Progress, Litera, - 272 p. (63) 